\title{
Impact of urban fires in drainage systems: an experimental case study
}

\author{
CARLA PIMENTEL-RODRIGUES ${ }^{1}$ \\ ${ }^{1}$ ISCIA - Higher Institute of Information Sciences and Administration \\ Av. Dom Manuel de Almeida Trindade, 3810-164 Aveiro \\ PORTUGAL
}
JOÃO ALMEIDA ${ }^{2,3}$
${ }^{2}$.Institute for Research and Technological Development in Construction, Energy, Environment and Sustainability
Rua Pedro Hispano, 3030-289, Coimbra
PORTUGAL
${ }^{3}$ University of Coimbra, Chemistry Centre, Department of Chemistry
3004-535, Coimbra
PORTUGAL

\author{
ARMANDO SILVA-AFONSO ${ }^{4,5}$ \\ ${ }^{4}$.RISCO, Department of Civil Engineering \\ University of Aveiro \\ Campus Universitário de Santiago, 3810-193 Aveiro \\ PORTUGAL \\ 5.ANQIP - Portuguese Association for Quality and Efficiency in Building Services \\ Operational Center of the University of Aveiro \\ Campus Universitário de Santiago, 3810-193 Aveiro \\ PORTUGAL \\ PEDRO BARREIRINHA ${ }^{1}$ \\ ${ }^{1}$ ISCIA - Higher Institute of Information Sciences and Administration \\ Av. Dom Manuel de Almeida Trindade, 3810-164 Aveiro \\ PORTUGAL
}

\begin{abstract}
The number of existing studies on the effect of urban fires on drainage systems and treatment facilities is relatively scarce. However, as shown in this paper, the water runoff generated during an urban firefighting can impact these systems. The maximum flow capacity of sewers or other components of the drainage systems can be exceeded. Contaminated water resulting from the fire combat can also impact on subsequent treatment operations taking place at domestic sewage treatment facilities or wastewater treatment plants. Further environmental concerns may be raised if these runoffs are discharged without any treatment. In this paper, a case study is presented to assess the possible effects of urban firefighting on drainage systems and treatment facilities. For this, a simulation of a fire in a traditional Portuguese dwelling was carried out, collecting and analysing the water effluent resulting from the firefighting. Potential physicochemical and hydraulic impacts were discussed taking into account European and Portuguese context. With this work, the authors aimed to provide authorities with information that allows planning or implementation corrective interventions that may be necessary to mitigate potential impacts in the case of urban fires.
\end{abstract}

Key-words: - urban fires; drainage systems; physicochemical impacts; hydraulic impacts Received: August 28, 2020. Revised: February 1, 2021. Accepted: February 10, 2021. Published: February 17, 2021. 


\section{Introduction}

Existing studies regarding the impacts of urban fires on public or building drainage systems are relatively scarce, in contrast to what happens with forest fires. However, since impact assessment and prevention actions underlying fires of any kind have points in common, a broader review of the literature is justified.

A study developed in 2015, for example, analyse the consequences of forest fires on the quality of surface water in terms of physical, chemical and biological properties, and discuss these effects regarding the leading factors in runoff on the slopes. They conclude that the impacts on water depend on the characteristics of precipitation, soil and vegetation cover at the site, as well as on the geology, topography and characteristics of the fire. They also point out that, in the case of forest fires, there may be immediate or delayed effects on the environment, suggesting management strategies for forests with a high risk of fire to prevent and minimize the impacts on water quality of streams and lakes [1].

The water quality risk due to fire disturbance, was also studied by other authors, proposing tools for its quantification. In this work, the authors investigate key landscape variables that can be used to quantify the risk across a large basin. They conclude that the risk responds directly to changes in fire and rainfall regimes, eliminating aspects related to a particular hillslope or hydrographic basin [2].

A technical report on the "effects of post-fire runoff on surface water quality" addresses questions related to water quality monitoring programs to assess how post-fire runoff affects contaminant flux, the effects of post-fire runoff on downstream receiving waters, and factors that influence the persistence of post-fire runoff effects. This Southern California Regional Program aims to contribute to address the current information gaps by providing post-fire water quality sampling procedures [3]. With the same objective, other authors [4] studied the effect of a forest fire on physicochemical properties of the water of São Domingos stream, in the Western Region of the Portugal. Measured data confirmed nutrient leaching by surface runoff from the burned areas with potential harmful impacts.

In addition to aspects related to impacts on water quality, risks related to soil erosion are also the subject of several specific studies in the case of forest fires, such as, for example, the discuss the sediment availability on burned hill slopes [5]. Regarding forest fires of moderate intensity, a study reports that they often produce hydrophilic soils, pointing out that, during the rains that follow the fire, water sheets and significant amounts of particles are thrown into water courses [6]. Several other studies linking erosion and risks to water resources are also available, such as the development of hydrogeomorphic response models for burned areas and their applications in land management [7] or the assessment of erosion and respective risks to water resources in the context of fire and rainfall regimes [8]. There's also a relevant as study on the modelling of the effects of fire and rainfall regimes on extreme erosion events in forested landscapes [9].

Additional remotely sensed information on fire severity [10], fire intensity [11], carbon emissions [12], burn scar extent [13] and fire detection [14] has been applied to both prevention and post-fire assessment actions. Although these studies are not directly applicable in the assessment of impacts from urban fires, they can provide clues for further studies, such as to analyse the dispersion of pollutants resulting from firefighting.

Despite the above revision, as previously stated, with regard specifically to urban fires, studies on their impacts on public drainage networks and wastewater treatment plants are practically non-existent, which justifies the need for theoretical and experimental research in this field. Some studies in this area have been found in the literature, but only in relation to hydrocarbon fires [15].

In this article, the impact on public and building drainage systems, as a result from the fight of urban fires, using water as extinguishing agent, is assessed both from a hydraulic and physicochemical point of view. With regard to hydraulic aspects, the possibility of exceeding the maximum capacity of the pipes and other components of the drainage system is evaluated. With regard to physicochemical aspects, the pollutants dragged into the drainage system are analysed, as well the potential consequences for sewers, wastewater treatment plants and the environment.

\section{Materials and Methods}

The experimental study was carried out in the training facilities of a fire brigade in Portugal (city of Ílhavo). In these facilities, a simulation of a living 
room in a residence equipped with a traditional furniture was carried out. The selection of the materials (e.g. sofas made of synthetic material from the 80 's and televisions from the 90 's) were based on the most common Portuguese dwellings.

The test cell used in this study $(5 \mathrm{~m}$ long, $4 \mathrm{~m}$ wide and $2,5 \mathrm{~m}$ high) has walls of metal and floor of concrete.

To allow the later collection and subsequent analysis of the effluent from firefighting, the materials were placed on a metal tray, as shown in Figure 1 (a).

The ignition was performed using a portable torch and was initiated on the sofas at three points, as shown in Figure 1 (b). After the ignition, the fire developed quickly and violently due to the materials that were on fire (e.g. synthetic fabrics and plastics). The fire took about 2 minutes to reach continuous combustion.

The fire was allowed to develop freely for a few minutes before starting extinction. Water from the public network at a temperature close to $15{ }^{\circ} \mathrm{C}$ was used as an extinguishing agent, employing a $45 \mathrm{~mm}$ hose with nozzle. Within minutes the fire was completely extinguished. As shown in Figure 1 (c), the televisions were completely consumed, leaving only the metal parts. The sofas burned by about $70 \%$ and almost all fabrics and synthetic materials burned, leaving the wooden structure still with some resistance.

Soon after the fire was extinguished, the effluent was collected from the tray, using appropriate containers, as shown in Figure 1 (d). The temperature measurement carried out in this phase indicated that the effluent was at $21^{\circ} \mathrm{C}$.

As can be observed in the photograph of firefighters' helmets after fire is extinguished (Figure 2), very black smoke was produced during combustion, suggesting that a large amount of particulate matter was transported to the water.

In an actual situation, the effluent resulting from the firefighting would be directed to the building's surrounding environment or to the building drainage network (through floor gullies, shower trays, etc.) and, from this, to the public network or to the individual home sewage treatment system. In case the effluents are sent to public systems, the hypotheses of discharge into a stormwater network, a wastewater network or a combined network are considered. The entry into stormwater networks can also occur through gutters, when water from the firefighting drains to the street.

Aiming to assess the potential impacts of the resulting effluent in drainage system and treatment operations downstream, as well as in the environment, a thorough physicochemical characterization was carried out. This included the determination of several general water quality indicators ( $\mathrm{pH}$, BOD5, COD, TSS, detergents), cations (aluminium, iron, manganese, arsenic, lead, cadmium, chromium, coper, nickel and mercury), anions (sulphide, sulphite, sulphate, ammonium, nitrate, cyanides), and organics (TOC, NT, mineral oils, phenols, formaldehyde).

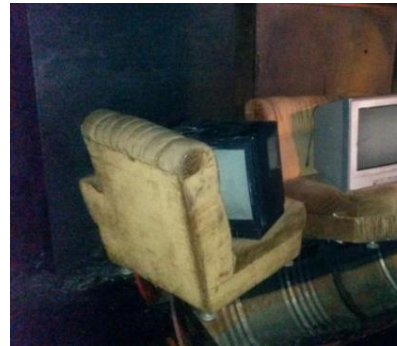

(a)

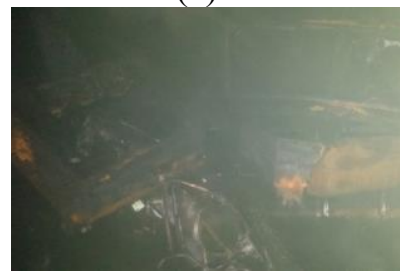

(c)

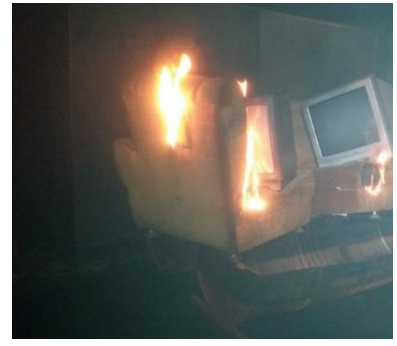

(b)

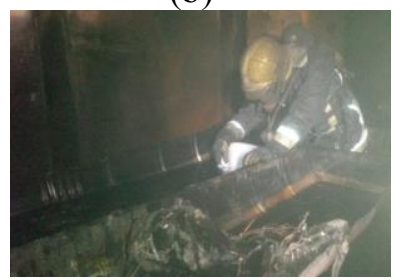

(d)
Fig. 1 Simulation of a fire in a traditional Portuguese dwelling: (a) combustible material before ignition; (b) ignition points and start of combustion; (c) fire extinguishing; and (d) collection of water after fire is extinguished.

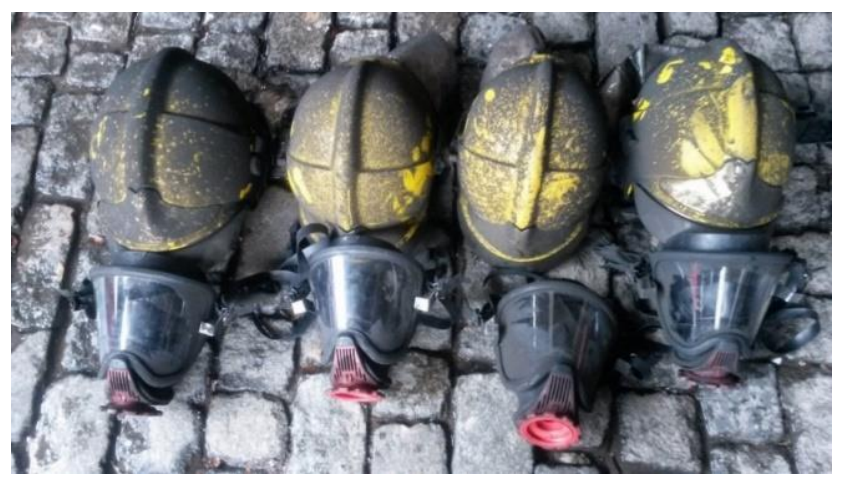

Fig. 2 Firefighters' helmets after fire is extinguished.

\section{Results and Discussion}

As previously stated, this study is not intended to address urban fires, but rather to assess the impact of its combat with water on the receiving environments, natural or artificial, bearing in mind that other experimental studies on the topic are not known.

The objective of the paper is, therefore, to provide the entities responsible for urban drainage systems and 
the conservation of natural systems with information that enables them, following an urban fire, to assess their impact on those systems and to plan the control or corrective interventions that may be necessary, and which may be significant.

\subsection{Physicochemical impacts}

As previously mentioned, the temperature of the water effluent was measured in the collection tray immediately after the fire is extinguished aiming to assess potential effects on the drainage system. However, the obtained value $\left(21^{\circ} \mathrm{C}\right)$ seems not raise concerns regarding the materials usually used in drainage networks. PVC-U, for example, widely used in recent decades in some countries, is the most sensitive to high temperatures among the various thermoplastic pipes that can be found for this purpose, like high density polyethylene (HDPE), polypropylene (PP), polybutylene (PB), acrylonitrile butadiene styrene (ABS) or chlorinated polyvinyl chloride (CPVC). Consulting the existing international standards for this material (e.g. EN 1401-1) [16], it can be concluded that these pipes can operate with service temperatures up to $30^{\circ} \mathrm{C}$ and support values up to $60{ }^{\circ} \mathrm{C}$ in short periods. In the case of the other thermoplastics, this value is even higher (not less than $80^{\circ} \mathrm{C}$ ). In cast iron, vitrified clay or concrete pipes, the values are significantly higher. In case the effluents are discharged on a public network, the effects in the pipes will still be less important, in view of the likely effect of mixing with other effluents at lower temperatures, since the temperature of the domestic sewage normally range between $10{ }^{\circ} \mathrm{C}$ and $20^{\circ} \mathrm{C}$.

In domestic or urban wastewater treatment plants (WWTPs), temperature is important in biological processes, because of its effects on microbial growth [17]. Bacterial adaptation is expected when there are slow changes in temperature, as it happens throughout the year. However, sudden changes in temperature can affect microbial activity and impair processes such as flocculation [18,20]. Activated sludge liquors, for example, are also less filamentous at higher temperatures. Additionally, as temperatures rise, the efficiency in reducing chemical oxygen demand (COD) is expected to decrease and the concentration of suspended solids (SS) is expected to increase. Note, however, that the temperature found by the authors in this case study was not significant taking into account the regular range of temperatures of the domestic sewage. Furthermore, in the case of urban WWTPs, the effect of mixing with other effluents along the network tends to nullify any risk of increasing temperature. Therefore, any impacts on the network and treatment facilities are unlikely.
However, when the water resulting from the firefighting is discharged directly into the surrounding environment of the building, the temperature may have some unspecific, possibly temporary, effects. Although hot water may have a beneficial effect against certain pests and pathogens and some plants are relatively tolerant to warm water, it is common sense that hot water is harmful for most vegetative species. Aquatic life, in turn, are sometimes sensitive to even minor temperature fluctuations.

In addition to the temperature, several physicochemical parameters were analysed according to reference methods and the results obtained compared with the limit values for discharges into sewage systems required by Portuguese legislation [21], which follows the European directives on the quality of water intended for human consumption and on pollution caused by certain dangerous substances discharged into the aquatic environment [22][23]. The results obtained are presented in Table 1, together with the limit values for discharges into domestic or unitary drainage networks. Note that these discharge limits take into account potential impacts on the drainage network and treatment facilities, as well as on treatment processes and receiving environment.

Analysing the results obtained, it can be seen that the discharge limits in public drainage networks are exceeded, sometimes significantly, with regard to chemical oxygen demand (COD), total suspended solids (TSS), total iron, oils and fats, sulphites, total lead, mineral oils and detergents. Taking into account the materials burned, relatively high values were expected for some parameters, but the analyses carried out allow to characterize more precisely its amplitude and the deviation from the regulatory values.

The presence of recalcitrant (or persistent) organic pollutants (POPs), which include numerous synthetic substances belonging to various chemical groups, are expected to contribute for the high values found for some parameters. POPs are resistant or difficult to biodegrade, are toxic or are inhibitory to bacterial growth, and present an increasing problem in water and wastewater treatment systems [24, 26]. Because of this, they have been observed to persist in the environment, to be capable of long-range transport, to bio accumulate in human and animal tissue, to bio accumulate throughout food chains, and to produce potential human health risks and ecological disturbances. 
Table 1. Physicochemical characterization of the effluent resulting from the firefighting

\begin{tabular}{|c|c|c|c|c|}
\hline Parameter & Unit & $\begin{array}{c}\text { Limit of } \\
\text { Quantification } \\
\text { (LOQ) }\end{array}$ & Result & $\begin{array}{c}\text { Discharge limit } \\
\text { value }^{\mathrm{i}}\end{array}$ \\
\hline pH & Sorensen & - & 6,7 & $6,0-9,0$ \\
\hline $\mathrm{BOD}_{5}, 2^{\circ} \mathrm{C}$ & $\mathrm{mg} / \mathrm{l} \mathrm{O}_{2}$ & 10 & $<$ LOQ & 40 \\
\hline COD & $\mathrm{mg} / 1 \mathrm{O}_{2}$ & 100 & 772 & 150 \\
\hline TSS & $\mathrm{mg} / 1$ & 2.0 & 173 & 60 \\
\hline Aluminium & $\mathrm{mg} / \mathrm{l} \mathrm{Al}$ & 0.20 & 5.6 & 10 \\
\hline Total iron & $\mathrm{mg} / \mathrm{l} \mathrm{Fe}$ & 0.10 & 2.6 & 2.0 \\
\hline Total manganese & $\mathrm{mg} / \mathrm{l} \mathrm{Mn}$ & 0.10 & 0.14 & 2,0 \\
\hline $\begin{array}{l}\text { Free residual } \\
\text { chlorine }\end{array}$ & $\mathrm{mg} / \mathrm{l} \mathrm{Cl} l_{2}$ & 0.25 & $<$ LOQ & 0.5 \\
\hline $\begin{array}{l}\text { Total residual } \\
\text { chlorine }\end{array}$ & $\mathrm{mg} / \mathrm{l} \mathrm{Cl} 2$ & 0.25 & $<$ LOQ & 1.0 \\
\hline Phenols & $\mathrm{mg} / 1 \mathrm{C}_{6} \mathrm{H}_{5} \mathrm{OH}$ & 0.05 & 0.42 & 0.5 \\
\hline Oil and fat & $\mathrm{mg} / \mathrm{l}$ & 0.05 & 47 & 15 \\
\hline Sulphides & $\mathrm{mg} / \mathrm{l} \mathrm{S}$ & 0.50 & 0.90 & 1.0 \\
\hline Sulphites & $\mathrm{mg} / 1 \mathrm{SO}_{3}$ & 1.0 & 1.4 & 1.0 \\
\hline Sulphates & $\mathrm{mg} / 1 \mathrm{SO}_{4}$ & 2.0 & 42 & 2,000 \\
\hline Total phosphorous & $\mathrm{mg} / \mathrm{l} \mathrm{P}$ & 0.80 & 1.1 & 10 \\
\hline Ammonium & $\mathrm{mg} / 1 \mathrm{NH}_{4}$ & 0.10 & 2.4 & 10 \\
\hline Total nitrogen & $\mathrm{mg} / \mathrm{l} \mathrm{N}$ & 1.0 & 9.3 & 15 \\
\hline Nitrates & $\mathrm{mg} / 1 \mathrm{NO}_{3}$ & 1.0 & 9.4 & 50 \\
\hline Formaldehyde & $\mathrm{mg} / \mathrm{l}$ & 0.060 & $<$ LOQ & 1.0 \\
\hline Total arsenic & $\mathrm{mg} / \mathrm{l} \mathrm{As}$ & 0.01 & 0.06 & 1.0 \\
\hline Total lead & $\mathrm{mg} / \mathrm{l} \mathrm{Pb}$ & 0.25 & 1.4 & 1,0 \\
\hline Total cadmium & $\mathrm{mg} / \mathrm{l} \mathrm{Cd}$ & 0.04 & $<\mathrm{LOQ}$ & 0.2 \\
\hline Total chromium & $\mathrm{mg} / \mathrm{l} \mathrm{Cr}$ & 0,10 & $<$ LOQ & 2.0 \\
\hline $\begin{array}{l}\text { Hexavalent } \\
\text { chromium }\end{array}$ & $\mathrm{mg} / \mathrm{l} \mathrm{Cr}(\mathrm{VI})$ & 0.050 & $<$ LOQ & 0.1 \\
\hline Total coper & $\mathrm{mg} / \mathrm{l} \mathrm{Cu}$ & 0.10 & 0.23 & 1.0 \\
\hline Total nickel & $\mathrm{mg} / \mathrm{l} \mathrm{Ni}$ & 0.25 & $<$ LOQ & 2.0 \\
\hline Total mercury & $\mathrm{mg} / \mathrm{l} \mathrm{Hg}$ & 0.02 & $<$ LOQ & 0.05 \\
\hline Total cyanides & $\mathrm{mg} / \mathrm{l} \mathrm{CN}$ & 0.050 & $<$ LOQ & 0.5 \\
\hline Mineral oils & $\mathrm{mg} / \mathrm{l}$ & 0.05 & 47 & 15 \\
\hline $\begin{array}{l}\text { Detergents (sodium } \\
\text { laurel sulphate) }\end{array}$ & $\mathrm{mg} / \mathrm{l}$ & 0.50 & 2.5 & 2.0 \\
\hline
\end{tabular}

${ }^{i}$ Portuguese Decreto-Lei $n^{\circ}$ 236/98 1998, de 1 de Agosto. Emission limit value understood as a monthly average. The daily value, determined on the basis of a representative sample of water discharged over a twenty-four hour period, cannot exceed twice the average monthly value. 
Various impacts from different POPs have been identified, the most eye catching being the endocrinedisrupting compounds (EDCs) which can apparently cause fish to change gender. Other POP health impacts have been identified to the reproductive system $[26,28]$. It should be noted that the Stockholm Convention, signed by 100 countries in May 2001 [27], currently prohibits the production of refractory organic pollutants, but the materials used in the experiment, which are still common in many households, are manufactured before this date.

Regarding the impact on treatment systems, the existence of a very high chemical oxygen demand (COD) seriously affects the efficiency of traditional biological or physicochemical treatment processes [28].

However, in the case of urban WWTPs, the dilution effect across the network can significantly fade the perceived peak of COD. This issue may be more problematic in relation to local or individual treatment systems (septic tanks, for example), but, in resistance to acids and sulphates. The limit value for sulphates (as shown in table 1) is very wide, but it should be noted that it targets domestic wastewater networks, where the use of concrete without interior protection is not usual. However, firefighting effluents can be conducted in a separate stormwater network, where concrete pipes without internal protection are often used. In the situation, where the discharge is made into a stormwater network, the benefit of dilution does not exist in periods of drought. In any case, the analytical value obtained is relatively low and will correspond to a situation of very limited duration in time, so it does not seem worthy of particular concern.

The cast iron tubes used in public or building sewage systems have factory interior protection, as a rule, which gives them increased chemical resistance. In this case, chemical resistance does not depend on ductile cast iron itself, but rather on the product used in the interior lining.

\subsection{Hydraulic impacts}

In most urban fires, only a percentage of the volumes of water used in combat are likely to enter the building's drainage systems. In the present study, however, the most unfavorable hypothesis is considered, that is, it is assumed that this volume may represent a large part of the volume used to fight the fire or even its entirety.

The most significant hydraulic impacts are related to the flows resulting from the firefighting, which are carried to the building and public drainage networks and can exceed the transport capacity of the pipes, as well as the increase in hydraulic loads in treatment any case, is to be expected that the individual treatment facility remains out of service after a severe fire in the building.

In relation to the pipes, most of the materials used in sewers resist to the concentrations found outside the legal limits, for the usual range of temperatures in drainage systems. PVC-U, for example, is resistant to most oils and fats and mineral oils, according to the manufacturers' chemical resistance tables. In the case of polypropylene, it can undergo some absorption and limited attack in contact with mineral oils, but only at relatively high temperatures (in the order of $60{ }^{\circ} \mathrm{C}$ ). The same can be said, roughly, in relation to polyethylene.

With regard to other materials used in drainage networks, it should be noted that the concrete is very susceptible to attack by acids and sulphates [29, 31]. Specific international standards, such as DIN 19573:2016-03, define experimental methods to test mortars used in construction and rehabilitation of drains and sewers outside buildings regarding their facilities. There may be other local impacts on some network components, such as lifting stations, who may be unable during some time to pump all the effluent that reaches the station.

The treatment facilities can reach a flow that is significantly higher than their design flow, temporarily impairing the biological or physicochemical treatment process or requiring the operation of weirs at the entrance, when they exist. However, in urban WWTPs, the problem may not be significant, given the volume that could be retained by storage throughout the network and the fact that, in all likelihood, the fire does not coincide with periods of peak flow in the network, at least in the area where it occurs. The same is not true for individual treatment facilities (septic tanks, etc.) where an unforeseen increase in flow can have a significant impact, temporarily affecting the treatment process and promoting the discharge to final destination of diluted effluents, but not properly treated.

Regarding piping, most international regulations consider minimum diameters of $100 \mathrm{~mm}$ in building drains and $200 \mathrm{~mm}$ in public drainage networks. In some countries, in separate rainwater networks or in combined networks, a minimum diameter of $300 \mathrm{~mm}$ is adopted. Although, for domestic sewage, European regulations (and a large part of international regulations) generally consider half-section flow, in an exceptional fire situation it is permissible that the flow in these pipes can be verified as full section (filling degree of 100\%).

Usually, drains in building networks are installed with slopes between $0.5 \%$ and $4 \%$, but in public 
networks, the maximum slope can be higher, up to $20 \%$, or more. According to the European Standard EN 12056-2 [32] and hydraulics manuals, the corresponding flow rates at full section are those indicated in Table 2.

Table 2. Hydraulic capacity of (a) building drains (DN 100) and (b) pipes in public drainage networks (DN 200, DN 300 ) with a filling degree of $100 \%$

\begin{tabular}{cccc}
\hline $\begin{array}{c}\text { Minimum } \\
\text { nominal } \\
\text { diameter } \\
\text { (DN) }\end{array}$ & $\begin{array}{c}\text { Slope of } \\
\mathbf{0 . 5 0 \%}\end{array}$ & $\begin{array}{c}\text { Slope of } \\
\mathbf{4 \%}\end{array}$ & $\begin{array}{c}\text { Slope of } \\
\mathbf{2 0 \%}\end{array}$ \\
\hline DN 100 & $3.61 / \mathrm{s}$ & $10.01 / \mathrm{s}$ & - \\
\hline DN 200 & $20.01 / \mathrm{s}$ & - & $130.01 / \mathrm{s}$ \\
\hline DN 300 & $61.01 / \mathrm{s}$ & - & $380.01 / \mathrm{s}$ \\
\hline
\end{tabular}

It should be noted that the indicated values may vary with the piping material. However, in a circular pipe with open channel flow, the maximum flow rate is not obtained for a $100 \%$ filling degree, but for $95 \%$ (for hydraulic reasons linked with the hydraulic radius, that is the relation between the section flow and the wetted perimeter), which gives some tolerance in relation to the values indicated in the table.

In case the firefighting is done with hoses $(45 \mathrm{~mm}$ hoses with $25 \mathrm{~mm}$ nozzle are usual in Portugal and other countries to fight urban fires, although larger

However, it should be noted that the high TSS value observed (Table 1) can cause significant deposits in the network, with a reduction in the useful flow section. In relation to public drainage systems, it means that, after the occurrence of an urban fire with outflow to the network, a cleaning operation should be carried out on the sewers.

In the event that the firefighting flows are conducted to a street and enter the stormwater network through gutters, there may also be obstructions in these network components, especially when they are equipped with siphon. The existence of siphon gutters is usual when there is a combined drainage system or when the stormwater network is subject to the effect of the tides.

Table 3 summarizes the possible impacts of an urban fire on public and building drainage systems and on individual or urban treatment facilities. The authors believe that the results of this work are representative of what could be expected from a typical urban firefighting in a Portuguese dwelling. However, in order to establish a more comprehensive rationale, in diameter hoses are also used in some situations), the flow rate depends on the pressure, as is known. In Portugal, when these hoses are connected to pressurization systems located in vehicles (UFFV Urban Fire Fighting Vehicle or UTTV - Urban Tactical Tank Vehicle), a reference flow rate of 8.3 $1 / \mathrm{s}$ per hose is generally adopted, with two hoses in simultaneous operation [33], meaning a total flow rate of $16.6 \mathrm{l} / \mathrm{s}$. It should be noted that a UFFV has a capacity of 3,000 liters and a UTTV has a capacity of 10,000 liters, which means that the emptying times of the tanks are relatively short (3 minutes and 10 minutes, respectively).

Portuguese legislation [34] also provides, inside buildings of high risk category, the installation of dry or wet riser systems, with the possibility of simultaneous operation of 4 indoor fire hydrants. In this case, the reference flow rate, according to European Standard EN 671-2:2012 [35], is 2.65 1/s at $350 \mathrm{kPa}$ in each hydrant (considering nozzles ref. D13), that is, a total of $10.61 / \mathrm{s}$.

Bearing in mind Table 2, it can be concluded that the risk of overflow in the public drainage network is very low, even if the combat is done from more than one vehicle. Indeed, the capacity of a pipe with the minimum diameter installed with the minimum slope is very superior to the reference flow rates (unless there are already significant flows from upstream in the entry section in the sewer). Regarding the building and considering the possibility of draining through the network, its capacity may be insufficient, resulting in water accumulation inside the building and overflow by other locations.

statistical terms, further experiments will have to be carried out, namely with different prototype configurations and fillings. Carrying out analytical controls downstream in urban drainage systems or at discharge points in natural systems, for a better assessment of the effects of dispersion or dilution of effluents resulting from firefighting could also be useful to complement and validate some of the conclusions. 
Table 3. Possible impacts of urban firefighting on drainage systems and treatment facilities using water as an extinguishing agent

\begin{tabular}{|c|c|c|c|}
\hline Compone & & Hydraulic impacts & Physicochemical impacts \\
\hline \multirow{2}{*}{ Drainage network } & Building & $\begin{array}{l}\text { High (lack of capacity, overflow, } \\
\text { blockage, clogging, etc.) }\end{array}$ & $\begin{array}{l}\text { High (possible impacts in } \\
\text { case of discharge for the } \\
\text { surrounding environment) }\end{array}$ \\
\hline & Public & $\begin{array}{c}\text { Reduced (possible section reduction } \\
\text { by sedimentation) }\end{array}$ & $\begin{array}{l}\text { Reduced (possible } \\
\text { corrosion problems in } \\
\text { concrete pipes) }\end{array}$ \\
\hline \multirow{2}{*}{$\begin{array}{l}\text { Treatment } \\
\text { facilities }\end{array}$} & Individual & $\begin{array}{c}\text { High (lack of capacity, overflow, } \\
\text { etc.) }\end{array}$ & $\begin{array}{l}\text { High (possible treatment } \\
\text { inhibition and impacts in } \\
\text { surrounding environment) }\end{array}$ \\
\hline & Urban & $\begin{array}{l}\text { Reduced (depending on the } \\
\text { dimension of the network and } \\
\text { WWTP) }\end{array}$ & $\begin{array}{l}\text { Reduced (depending on the } \\
\text { dimension of the network } \\
\text { and WWTP) }\end{array}$ \\
\hline
\end{tabular}

\begin{tabular}{cccc} 
Other components & $\begin{array}{c}\text { Lifting } \\
\text { stations }\end{array}$ & $\begin{array}{c}\text { High (Lack of capacity, overflow, } \\
\text { blockage, clogging, etc.) }\end{array}$ & Not identified \\
\cline { 2 - 5 } & $\begin{array}{c}\text { Street the system } \\
\text { gutters }\end{array}$ & $\begin{array}{c}\text { Reduced (Risk of sedimentations in } \\
\text { case of discharge of water from the } \\
\text { firefighting to the streets) }\end{array}$ & Not identified \\
\hline
\end{tabular}

\section{Conclusions}

The main effects of urban firefighting using water as an extinguishing agent may be, in the case of buildings, the lack of capacity of the interior drainage networks to drain the water and possible disturbance of biological processes on the individual treatment facilities, when they exist. For physico-chemical reasons, runoff into the building's surroundings can also lead to environment impacts.

In the case of public drainage networks, the hydraulic capacity of the sewers will not, in principle, be a problem, although deposits or even obstructions may occur in the pipes. Regarding WWTPs, the most troublesome aspect is the potential presence of refractory and toxic organic compounds in the effluent, which can affect the efficiency of traditional biological or physicochemical treatment processes. However, the dilution effect of such pollutants along the network, i.e. before reaching the WWTP, is expected to lessen these impacts. It is admitted, therefore, that the overall impact on the aquatic receiving environment may not be significant.

Other components of the public systems, such as the lifting stations (LWWSs), may also have malfunctions, with incapability to drain all the effluent. The operation of emergency discharges in WWTPs and LWWSs with this type of effluent can further impact on the surrounding environment.

Finally, with regard to the effluent temperature, high values are not expected. Therefore, harmful effects on the sewers' materials, on the functioning of the treatment facilities or on the receiving environment are unlikely, especially in public systems.

The results of this study may encourage further research on the topic, aiming to provide authorities with better guidelines for reducing the impact of urban firefighting in drainage systems and ecosystems. 


\section{References}

[1] Tecle, A., Neary, D. Water quality impacts of forest fires. Journal of Pollution Effects \& Control 2015, 3:3, 1-7.

[2] Nyman P. et al. Water quality risk due to fire disturbance: tools for quantifying. In Proceedings of AFAC13 - Shaping Tomorrow Together, Melbourne, Australia, September 2013, 2-5.

[3] Stein, E., Brown, J. Effects of post-fire runoff on surface water quality; development of a Southern California Regional Monitoring Program with management questions and implementation recommendations, Southern California Coastal Water Research Project, Technical Report 598, California, USA, 2009.

[4] Meneses, B., Cortez, N. Efeito de um incêndio florestal nas propriedades físico-químicas da água da ribeira de S. Domingos (Região Oeste de Portugal). Recursos Hídricos 2015, 36, 5-14. (in Portuguese).

[5] Nyman P. et al. Sediment availability on burned hillslopes. JGR: Earth Surface 2013, 118:4, 2451-2467.

[6] Capela, J. Efeitos de incêndios sobre a qualidade da água em áreas florestais, M.Sc. Dissertation, University of Aveiro, Aveiro, Portugal, 2008 (in Portuguese).

[7] Nyman P., Sheridan, G. Hydro-geomorphic response models for burned areas and their applications in land management. Progress in Physical Geography 2013, 37:6, 787-812.

[8] Nyman P. et al. Erosion and risk to water resources in the context of fire and rainfall regimes. In Proceedings of Bushfire CRC \& AFAC11 - Conference Science Day, Sydney, Australia, September 2011.

[9] Jones O. et al. Modelling the effects of fire and rainfall regimes on extreme erosion events in forested landscapes. Stochastic Environmental Research and Risk Assessment, 2015, 28:8, 2015-2025.

[10] Keeley, J.E. Fire intensity, fire severity and burn severity: a brief review and suggested usage. International Journal of Wildland Fire, 2009, 18(1), pp.116-126.

[11] Hammill, K.A. and Bradstock, R.A. Remote sensing of fire severity in the Blue Mountains: influence of vegetation type and inferring fire intensity. International Journal of Wildland Fire, 2006, 15(2), pp.213-226.

[12] Garcia, M., Saatchi, S., Casas, A., Koltunov, A., Ustin, S., Ramirez, C., Garcia-Gutierrez, J. and Balzter, H. Quantifying biomass consumption and carbon release from the California Rim fire by integrating airborne LiDAR and Landsat OLI data. Journal of Geophysical Research: Biogeosciences, 2017, 122(2), pp.340-353.

[13] Padilla, M., Stehman, S.V., Ramo, R., Corti, D., Hantson, S., Oliva, P., Alonso-Canas, I., Bradley, A.V., Tansey, K., Mota, B. and Pereira, J.M. Comparing the accuracies of remote sensing global burned area products using stratified random sampling and estimation. Remote sensing of environment, 2015, 160, pp.114-121.

[14] Dehong, D., Zhu, S. A method of forest-fire image recognition based on AdaBoost-BP algorithm, International Journal of Circuits, Systems and Signal Processing, 2019, 13, 312-319.

[15] Nolan, D. Handbook of Fire and Explosion Protection Engineering Principles for the Oil, Gas, Chemical, and Related Facilities (4th Edition); ScienceDirect, Elsiever, 2019.

[16] CEN, European Standard EN 1401-1:2009Plastics piping systems for non-pressure underground drainage and sewerage Unplasticized poly(vinyl chloride) (PVC-U) Part 1: Specifications for pipes, fittings and the system, 2009.

[17] Nedwell, D. Effect of low temperature on microbial growth: lowered affinity for substrates limits growth at low temperature. Microbiology Ecology 1999, 30:2, 101-111.

[18] Ratnaweera H., Fettig J. State of the Art of Online Monitoring and Control of the Coagulation Process. Water 2015, 7, 6574-6597.

[19] Liu T, Liu S, Zheng M, Chen Q, Ni J Performance Assessment of Full-Scale Wastewater Treatment Plants Based on Seasonal Variability of Microbial Communities via High-Throughput Sequencing. PLoS ONE, 2016, 11(4): e0152998.

[20] Wang Q., Wei W., Gong Y., Yu Q., Li Q., Sun J., Yuan Z. Technologies for reducing sludge production in wastewater treatment plants: State of the art. Science of the Total Environment 2017, 587-588, 510-521. 
[21] Decreto-Lei $n .^{\circ} 236 / 98$, de 1 de Agosto, Diário da República - I Série A N. ${ }^{\circ} 176$ - 1-8-1998 (in Portuguese).

[22] Council Directive 98/83/EC of 3 November 1998 on the quality of water intended for human consumption, Official Journal of the European Communities, 1998.

[23] European Commission, Council Directive 76/464/EEC of 4 May 1976 on pollution caused by certain dangerous substances discharged into the aquatic environment of the Community, Official Journal of the European Communities, 1976.

[24] Cretin M., Lesage G. Biorefractory Pollutants. In: Drioli E., Giorno L. (eds) Encyclopedia of Membranes. Springer, Berlin, Heidelberg, 2015.

[25] Delay M., et al. Nanoparticles and refractory organic matter: Interactions and consequences. Journal of Environmental Chemical Engineering 2015, 3:4B, 2997-3004.

[26] Lesage, G. et al. Persistent organic pollutants. In: Drioli E., Giorno L. (eds) Encyclopedia of Membranes. Springer, Berlin, Heidelberg, 2015.

[27] UNITED NATIONS, Stockholm Convention on Persistent Organic Pollutants, 2001.

[28] Clair N. et al. Chemistry for Environmental Engineering and Science (5th Edition); McGraw-Hill, 2003.

[29] Sturm P., Gluth G.J.G., Jäger C., Brouwers H.J.H., Kühne H.-C. Sulfuric acid resistance of one-part alkali-activated mortars. Cement and Concrete Research 2018, 109, 54-63.

[30] Girardi F., Di Maggio R. Resistance of concrete mixtures to cyclic sulfuric acid exposure and mixed sulfates: Effect of the type of aggregate. Cement \& Concrete Composites 2011, 33, 276285.

[31] Yuan H., Dangla P., Chatellier P., Chaussadent T. Degradation modeling of concrete submitted to biogenic acid attack. Cement and Concrete Research 2015, 70, 29-38.

[32] EN 12056-2:2000 - Gravity Drainage Systems Inside Buildings - Part 2: Sanitary Pipework, Layout and Calculation, 2000.

[33] Barreirinha, P. Avaliação do impacto do combate a um incêndio urbano nos sistemas de drenagem e tratamento de águas residuais $e$ pluviais, ISCIA, Portugal, 2016 (in Portuguese).
[34] Portaria $n^{o} 1532 / 2020$ - Regulamento técnico de segurança contra incêndio em edifícios, 2020 (in Portuguese).

[35] CEN - European Standard EN 671-2:2012 Fixed firefighting systems - Hose systems - Part 2: Hose systems with lay-flat hose, 2012.

\section{Contribution of individual authors to the creation of a scientific article (ghostwriting policy)}

Author Contributions: Conceptualization, P.B. and A.S.-A.; methodology, P.B. and J.A.; validation, A.S.-A. and J.A.; formal analysis, A.S.-A. and C.P.R.; investigation, P.B. and C.P.-R.; writing-original draft preparation, A.S.-A.; writing-review and editing, C.P.-R. and J.A.; supervision, A.S.-A. All authors have read and agreed to the published version of the manuscript.

\section{Sources of funding for research presented in a scientific article or scientific article itself \\ Not applicable.}

\section{Creative Commons Attribution License 4.0 (Attribution 4.0 International, CC BY 4.0)}

This article is published under the terms of the Creative Commons Attribution License 4.0

https://creativecommons.org/licenses/by/4.0/deed.en_US 